TERAKREDITASI Berdasarkan SK Dirjen Dikti Depdiknas Nomor: 65a/DIKTl/Kep/2008

MENIMBANG KOMPATIBELITAS MULTIKULTURALISME DAN ISLAM: IKHTIAR MENGGAGAS PENDIDIKAN ISLAM MULTIKULTURAL DI INDONESIA Mukhlis

ASESMEN AKHLAK MULIA: Suatu Model Alternatif Penilaian Pembelajaran Agama Siti Muri'ah

MENILAI Ulang GAGASAN NEGARA KHILÂFAH ABÛ AL-A'LÂ AL-MAUDÛDî Arsyad Sobby Kesuma

AL-A'IMMAH MIN QURAISY: ANTARA DOKTRIN DAN KEBUTUHAN SOSIAL Ahwan Mukarrom

SISTEM KALENDER ISLAM DALAM PERSPEKTIF EVOLUSI SYARI'AA Abd. Salam

Desain DakWAH untuk PEMBINAan KeAgamaAn KOMUNITAS ELIT INTELEKTUAL Bukhari 


\section{PEDOMAN TRANSLITERASI}

\begin{tabular}{|c|c|c|c|}
\hline Arab & Latin & Arab & Latin \\
\hline 1 & $=$ & = & $=\mathrm{f}$ \\
\hline ب & $=$ & ق & $=\mathrm{q}$ \\
\hline$\dot{H}$ & ts & ك & $=\mathrm{k}$ \\
\hline 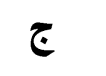 & $=$ & $J=$ & $=1$ \\
\hline$\tau$ & $=$ & b & $=\mathrm{m}$ \\
\hline$\dot{\tau}$ & $=\quad \mathbf{k h}$ & ن & $=\mathbf{n}$ \\
\hline$د$ & $=$ & و & $=\mathbf{w}$ \\
\hline$\dot{j}$ & $\mathrm{dz}$ & $\Delta$ & $=\mathbf{h}$ \\
\hline J & $=$ & $\varepsilon$ & $=$, \\
\hline j & $=$ & 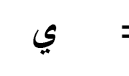 & $=\mathbf{y}$ \\
\hline س & $=$ & & \\
\hline ش ش & $\begin{array}{l}=\quad \text { sy } \\
=\quad \text { sh }\end{array}$ & \multicolumn{2}{|c|}{$\begin{array}{l}\text { Untuk Madd } \\
\text { dan Diftong }\end{array}$} \\
\hline ض & dl & $i$ & $=\hat{a}$ (a panjang) \\
\hline b & th & = & $=\hat{\mathbf{i}}(\mathbf{i}$ panjang $)$ \\
\hline ظ & $\mathbf{z h}$ & أو = & $=\hat{\mathbf{u}}$ (u panjang) \\
\hline$\varepsilon$ & $=$ & آو = & $=\mathbf{a w}$ \\
\hline$\dot{\varepsilon}$ & $=\mathbf{g h}$ & = آين & $=$ ay \\
\hline
\end{tabular}




\section{ISI}

TRANSLITERASI

ARTIKEL

Mukhlis

Menimbang Kompatibelitas

Multikulturalisme dan Islam:

Ikhtiar Menggagas Pendidikan Islam

Multikultural di Indonesia • 201-224

Siti Muri'ah

Asesmen Akhlak Mulia:

Suatu Model Alternatif Penilaian

Pembelajaran Agama • 225-248

Yusuf Hanafi

Perkawinan Anak di Bawah Umur

dalam Perspektif Hukum Islam • 249-274

Arsyad Sobby Kesuma Menilai Ulang Gagasan Negara Khilâfah

Abû al-A'lâ al-Maudûdî • 275-300

Ahwan Mukarrom Al-A'immah min Quraisy:

Antara Doktrin dan Kebutuhan

Sosial • 301-322

Abd. Salam

Sistem Kalender Islam dalam Perspektif

Evolusi Syari'ah • 323-350

Bukhari

Desain Dakwah untuk Pembinaan

Keagamaan Komunitas

Elit Intelektual • 351-370

Ahmad Munir Teologi Properti:

Telaah Eksistensi dan Fungsi

Kekayaan • 371-392

BOOK REVIEW

Ahmad Fathan Aniq Discovering Indonesian Islam through Fatâwâ • 393-408

INDEKS 


\title{
MENILAI ULANG GAGASAN NEGARA KHILÂFAH ABÛ AL-A'LÂ AL-MAUDÛDÎ
}

\author{
Arsyad Sobby Kesuma*
}

\begin{abstract}
In the midst of unstable democracy system, the idea about Islamic state or khilâfah, referring to some Muslim thinkers' views, begins to get fresh wind. This writing presents al-Maududi's view on Islamic state and khilâfah system centered in theo-democracy that is still unclear how to be implemented in the real practice especially in our situation now. Substantially, his basic ideas are acceptable, for example his thought of goals and functions of state establishment. However, his view that only men are eligible to be 'amîr is difficult to accept for public today. Al-Maududi is one of Muslim scholars who is persevering in establishing an Islamic state based on al-Qur'an and Hadist. Basically, al-Maududi agrees any state form. However, he emphasizes the significance of theo-democracy state model as a characteristic of an Islamic state that is different from republic system that applies democracy in the West.
\end{abstract}

Keywords: Pemikiran Politik, Negara Islam, Khilâfah, TeoDemokrasi, 'Amîr.

KAJIAN tentang hubungan Islam dan politik di dunia Islam merupakan salah satu tema kajian yang tidak pernah usai untuk diperbincangkan. Pelbagai teori dan pemikiran alternatif yang ditawarkan oleh kalangan cendekiawan Islam telah muncul baik pada masa klasik maupun modern. Riak polemik itu juga melanda negeri Indonesia. Belum lama ini, isu pendirian negara

*Penulis adalah dosen Institut Agama Islam Negeri (IAIN) Raden Intan Lampung. email: asob_kesuma@yahoo.com 
Islam atau khilâfah islâmiyah dengan mengusung formalisasi syari'at Islam sebagai undang-undang resmi negara gencar disuarakan oleh beberapa organisasi keagamaan dan politik. Bahkan, bukan hanya sekedar isu, pemikiran ke arah pembentukan negara khilâfah sudah menjadi agenda yang tertata rapi di kalangan sebagian kelompok muslim.

Dari hari ke hari wacana khilafah makin kencang dilontarkan oleh sebagian kelompok umat Islam, lebih-lebih setelah jatuhnya Khilâfah Utsmâniyah pada tanggal 03 Maret 1924. Masalahnya sekarang, bagaimana konsep negara atau khilafah dalam Islam dan bagaimana pula keberadaan negara-negara nasional sekarang dikaitkan dengan konsep khilâfah masa silam? Untuk menjawab pertanyaan ini ada beberapa pandangan yang digunakan dan menjadi problem epistemologis sepanjang masa, khususnya di kalangan fuqahâ' siyâsah.

Setidaknya ada tiga kelompok ilmuwan Islam yang mempunyai pandangan berbeda dalam menjawab permasalahan di atas, dan masing-masing kelompok tersebut sampai saat ini masih eksis menyuarakan pendapatnya bahkan semakin serius. Pertama, antara agama dan negara tidak dapat dipisahkan (integrated). Menurut kelompok ini, wilayah agama juga adalah wilayah politik. Dengan kata lain, negara merupakan lembaga politik dan sekaligus lembaga keagamaan. Menurut pemikiran kelompok model ini, negara diselenggarakan atas dasar kedaulatan Tuhan. Penganut teori ini menurut Din Syamsuddin adalah kelompok Syi'ah. Kedua, mereka yang memandang antara agama dan negara berhubungan secara simbolik. Menurut kelompok ini, antara agama dan negara terdapat hubungan timbal balik yang saling memerlukan. Dalam hal ini, agama memerlukan negara karena dengan kekuasaan negara agama akan dapat diaplikasikan dalam dunia nyata dan berkembang. Sebaliknya, negara dengan adanya peran agama akan terkontrol dari hal yang menyimpang. Di antara mereka yang menganut teori ini adalah al-Mâwardî, al-Ghazâlî, dan Fazlur Rahman. 
Ketiga, antara agama dan negara bersifat sekularistik. Kelompok yang menganut teori ini melakukan penolakan atas penyatuan peran agama dan negara dan menolak pendasaran negara kepada Islam. Di antara mereka yang menganut teori ini adalah Alî 'Abd al-Razîq. ${ }^{1}$ Argumentasi yang disodorkan oleh kelompok ini bahwa Islam tidak mempunyai kaitan apa pun dengan sistem kekhalifahan. ${ }^{2}$

Tulisan ini hendak memotret pemikiran negara Islam dan konsep khilâfah islâmiyah yang dikembangkan oleh Abû al-A'lâ alMaudûdî. Tokoh ini dipilih untuk dikaji lebih lanjut pemikiran politiknya karena pemikirannya cukup dikenal, setidaknya melalui buku-buku terjemahan dan menjadi referensi bagi komunitas muslim di negeri ini yang menggandrungi konsep khilâfah. Tidak sebatas mendeskripsikan, tulisan ini juga bermaksud mengkritisi dan menilai ulang konsep al-Maudûdî serta melihat kemungkinan aplikasinya bagi masyarakat Indonesia kontemporer.

\section{Sekilas Biografi Abû al-A’lâ al-Maudûdî}

Abû al-A’lâ al-Maudûdî (selanjutnya ditulis al-Maudûdî) lahir pada tanggal 3 Rajab 1321 Hijriyah, bertepatan dengan tanggal 25 September 1903 M, di Aurangabad, suatu kota terkenal di Kesultanan Hyderabad (Decan), sekarang masuk wilayah Andhra Predes di India. ${ }^{3}$ Jika dilihat dari garis silsilahnya,

${ }^{1}$ Lihat buku Alî 'Abd al-Razîq, al-Islâm wa Ushâl al- $\underline{H} u k m$ (Kairo: alQâhirah, 1925).

${ }^{2}$ M. Din Syamsuddin, "Usaha Pencarian Konsep Negara Dalam Sejarah Pemikiran Politik Islam", Jurnal Ulumul Qur'an, vol. 4 no. 2, 1993, 4-9. Lihat juga Din Syamsuddin, Islam dan Politik Era Orde Baru (Jakarta: Logos Wacana Ilmu, 2001), 87-144.

3India merupakan republik federasi di Asia Selatan dengan ibu kota New Delhi, wilayahnya seluas $3.166 .414 \mathrm{~km}$. Negeri ini terletak di antara laut Arab di sebelah barat dan Teluk Benggala di timur. Di sebelah utara, negeri ini berbatasan dengan pegunungan Himalaya, Republik Rakyat Cina, dan Nepal. Di sebelah timur berbatasan dengan Myanmar. Di sebelah timur laut 
nampaknya al-Maudûdî dilahirkan dari keturunan keluarga terhormat, nenek moyangya dari garis ayah adalah keturunan dari Nabi Muhammad saw., karena itu pada namanya ia memakai nama "sayyid". Tidak hanya itu, dilihat dari beberapa catatan sejarah yang menceritakan latar belakang keluarganya, nenek moyang al-Maudûdî berasal dari para syaikh besar pengikut tarekat, yakni tarekat Chistiyah, ${ }^{4}$ yang banyak berperan dalam penyebaran dan pengembangan Islam di India. Menurut sejarah, keluarga al-Maudûdî mempunyai kedekatan khusus dengan Dinasti Moghul, terutama selama pemerintahan penguasa terakhir, yakni Bahadûr Syah Zhafar.

Menarik untuk dilihat sisi kontroversi nama dari tokoh ini. Jika dilihat dari makna namanya, Abû al-A'lâ artinya "Ayah dari Yang Maha Kuasa”. Sedangkan nama al-A'lâ (Yang Maha Kuasa) merupakan salah satu atribut nama Tuhan. Nama yang disandang al-Maudûdî ini menuai kritikan dari pihak-pihak tertentu. Melihat kondisi ini, al-Maudûdî pun berang dan menganggap perlu menanggapi kritikan itu. Dilihat dari keseriusan bantahan al-Maudûdî terhadap kritikan itu, nampaknya kontroversi di seputar nama itu cukup besar dan mengganggu al-Maudûdî, sehingga ia merasa perlu melakukan klarifikasi atau penjelasan terhadap namanya. Ia menjelaskan dengan mengutip dua ayat dari al-Qur'an yang terdapat kata alA'lâ dan al-A'lawna, bentuk jamak dari A'lâ, diberikan kepada

berbatasan dengan Bangladesh. Di sebelah barat laut berbatasan dengan Pakistan dan Afganistan serta di sebelah selatan berbatasan dengan Samudera Hindia.

${ }^{4}$ Tarekat Chistiyah adalah tarekat sufi di Asia Selatan. Namanya terambil dari sebuah desa, yaitu Desa Chisht, di Afghanistan bagian barat. Pendirinya

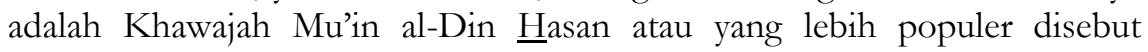
dengan Mư̂̀n al-Dîn Chistiyah (w. 1236), figur karismatik yang diliputi berbagai lagenda. Tarekat ini tersebar di kawasan India, Pakistan, dan Bangladesh. Lihat Media Zaenul Bahri, "Tarekat Chistiyah; Tarekat Terkenal di India" dalam Sri Mulyati (et.al), Mengenal dan Memahami Tarekat-tarekat Muktabarah di Indonesia (Jakarta: Kencana, Cet. II, 2005), 293-318. 
manusia yakni kepada Nabi Musa as. dan kepada orang-orang yang beriman. ${ }^{5}$

Selama kariernya sebagai seorang pemikir dan penulis, tidak kurang dari 130 buku telah dihasilkannya. ${ }^{6}$ Dari sekian banyak karya yang ditulis dengan bahasa Arab, Inggris, dan Urdu, alMaudûdî membahas berbagai disiplin ilmu; tafsir, hadis, sejarah, politik, hukum Islam, ekonomi, dan lain sebagainya. Kehadiran karya-karya al-Maudûdî ternyata mendapat respons yang hangat dari masyarakat luas, bukan hanya di India dan Pakistan, akan tetapi di seluruh dunia. Hal tersebut terbukti dengan hampir semua karya al-Maudûdî sudah diterjemahkan ke dalam berbagai bahasa. $^{7}$

Salah satu di antara judul karyanya yang terkait dengan konsep negara dan agama adalah "The Islamic Law and Constitution". Buku ini berisi uraian konsep pemikiran politik alMaudûdî. Sajian dalam buku ini terbagi dalam dua bagian; pertama, membahas aspek-aspek hukum Islam yang meliputi legislasi dan ijtihad dalam Islam, serta upaya-upaya konstruktif penegakan hukum Islam dalam suatu negara. Kedua, membahas pemikiran politik dan konstitusi Islam, yang meliputi

\footnotetext{
${ }^{5}$ Munawir Syadzali, Islam dan Tata Negara; Ajaran, Sejarah, dan Pemikiran (Jakarta, UI Press, 1993), 158.

GUntuk mengetahui daftar tulisan al-Maudûdî bisa dilihat dalam volume kenangan yang dipersembahkan kepadanya sesudah ia meninggal dunia. Buku tersebut berjudul Islamic Perspectives; Studies in Honour of Maulana Sayyid Abû al-A'lâ Al-Maudûdî, disunting oleh Khurshid Ahmad dan Zafar Ishaq Anshari, dan diterbitkan oleh The Islamic Foundation, U.K in Association With Saudi Publishing House, Jeddah terutama pada bab 2 halaman 3-10.

${ }^{7}$ Menurut hasil penelusuran Samir 'Abd al-Hamîd Ibrâhîm, bahwa pada tahun 1977 saja karya al-Maudûdî sudah diterjemahkan ke dalam 22 bahasa. Ia menuturkan penerjemahan karya al-Maudûdî ke dalam bahasa Inggris sebanyak 34 buah, bahasa Arab 48 buah, bahasa Bangladesh 43 buah, bahasa Sind 24 buah, bahasa Punjab 15 buah, bahasa Mahrathi 9 buah, bahasa Turki 8 buah, bahasa Perancis 9 buah. Samir Abdul Hamid Ibrahim, Teladan Bagi Generasi Pejuang, ter. Fathurrahman Hamid (Jakarta: Pustaka Qalami, 2004), 91-2.
} 
pembahasan teori politik Islam, konsep politik al-Qur'an, prinsip-prinsip dasar pemerintahan Islam, landasan konstitusi Islam menurut al-Qur'an dan al-Sunnah, dan pada bagian akhir menguraikan hak-hak non-muslim di suatu negara Islam. Buku lainnya berjudul "Niz̧hâm alditerjemahkan ke dalam bahasa Inggris "Islamic Way of Life". Buku berjudul "Tanqîh $\underline{a} t$ " diterjemahkan ke dalam bahasa Inggris "Antidote Against Superfities and Aping the Western Way of Life". Buku lainnya, ada yang semula dari artikelnya yang diterbitkan di al-Jam'iyyât, sebuah koran yang diterbitkan oleh Jam'iyyât-i Ulamâ-i Hindî. Artikel yang diterbitkan secara berkala itu kemudian pada tahun 1927 dikumpulkan menjadi sebuah buku dengan judul "Jihâd fi al-Islâm". ${ }^{8}$ Setelah buku ini hadir di tengahtengah masyarakat, ia mengatakan bahwa ini merupakan faktor yang menentukan yang membuatnya memahami sepenuhnya cara hidup Islam. ${ }^{9}$ Dilihat dari konsep jihad yang ia sajikan dalam buku tersebut, nampaknya ia merujuk kepada konsep yang dibuat oleh Ibnu Taymiyah dan Ibn Qayyim dengan tanpa menyebutkan namanya secara jelas. Dalam buku ini juga, alMaudûdî mengkritik konsep jihad yang ditawarkan oleh seorang ulama India, Abû Kalâm Azâd. ${ }^{10}$

${ }^{8}$ Menurut Azyumardi Azra, bahwa respons al-Maudûdî dalam bukunya Jihâd fi al-Islâm lebih tepat disebut pembelaan seorang "fundamentalis modern" terhadap doktrin ortodoks tradisional. Azyumardi Azra, "Jihad dan Revolusi Islam; Pandangan Al-Maudûdî", dalam buku Pergolakan Politik Islam; Dari Fundamentalisme, Modernisme Hingga Post-Modernisme (Jakarta: Paramadina, 1996), 162.

2Abû al-A'lâ al-Maudûdî, Jamâ'ati Islâmî, us ka Maqsad, Tarikh, awr La laibi Aml (The Jamâ'ati Islâmî; Its Aim, History and Programme) (Lahore: Markazi Maktabah Jamâ'ati Islâmî, cetakan keempat, 1953), 22.

10Abû Kalâm Azâd adalah seorang pemikir Islam India. Ia dilahirkan di Mekkah. Ayahnya adalah Khair al-Dîn Dihlawî bermigrasi pada tahun 1858 dan kemudian menikah dengan putri mufti Madinah. Nenek moyang Azâd memiliki hubungan intelektual dengan Syakh Ahmad Sirhindi, Syah Wali Allâh Dihlawî dan Syah 'Abd Al-Azîz. Ayah Azâd adalah seorang 'alim pir 


\section{Gagasan al-Maudûdî tentang Negara Islam dan Sistem Khilâfah}

Konsep al-Maudûdî tentang negara dilatarbelakangi oleh konsepnya tentang kebutuhan akan sebuah kekuasaan dalam rangka merealisasikan pesan-pesan al-Qur'an dalam kehidupan nyata. Karena menurutnya, al-Qur'an tidak hanya meletakkan prinsip moralitas dan etika, melainkan juga memberikan tuntunan-tuntunan di bidang politik, sosial, dan ekonomi. Ditetapkan pula tuntunan hukuman untuk kejahatan-kejahatan tertentu dan demikian juga ditetapkan prinsip-prinsip kebijaksanaan fiskal dan moneter. Ini semua tidak dapat terealisir dan dipraktikkan dalam kehidupan nyata, kecuali jika suatu negara Islam yang akan menegakkannya. Di sinilah menurut alMaudûdî pentingnya sebuah pembentukkan negara Islam sebagai pelaksana syari'at Islam yang telah ditentukan dalam alQur'an. Konsep al-Maudûdî tersebut muncul dari penjelasan alQur'an (Qs. al-Nûr [24]: 2).

Menurut al-Maudûdî, agama Islam melalui al-Qur'an tidak hanya terkait dengan permasalahan ibadah saja, seperti shalat, puasa, haji, dan zakat, tetapi juga termasuk hukum negara dan institusi kenegaraan. Jika kita ingin menegakkan agama Allah, maka tujuan itu tidak dapat dicapai hanya dengan menegakkan pranata puasa dan shalat, kita harus menegakkan hukum Illahi dan menjadikan syari'at sebagai undang-undang negara. Jika ini tidak ditegakkan, maka meskipun pranata shalat dan sebagainya dilaksanakan, tidak akan menyebabkan ditegakkannya agama. Ia hanya akan merupakan penegakkan sebagian saja dari dîn, bukan dîn secara total. Jika yang ditegakkan justru hukum-hukum lain

(guru sufi yang alim) dan bersikap anti Wahabi. Keluarga ini pindah ke Kalkuta pada tahun 1898. Untuk mengetahui latar belakang kehidupan Azâd dan karya-karyanya dapat dilihat dalam buku Ian Henderson Douglas, $A b \hat{u}$ Kalâm Azâad: An Intellectual and Religious Biography disunting oleh Gail Minault dan Christian W. Troll. New Delhi, 1988. 
selain hukum Tuhan, maka merupakan penolakan atas dîn itu sendiri. ${ }^{11}$ Ayat al-Qur'an lain yang dijadikan sandaran oleh alMaudûdî adalah Qs. al-Isrâ' (17): 80.

Al-Maudûdî memahami ayat ini dengan "berikan aku kekuasaan dan beri aku bantuan dari otoritas yang berkuasa, yaitu negara, sehingga aku-dengan bantuan kekuasaan tersebut serta sumber-sumber kekuasaan memaksa dari negara-mampu menegakkan kebajikan, membasmi kejahatan, menumbangkan korupsi, kecabulan dan dosa, meluruskan kebengkokankebengkokan yang telah menjalari kehidupan sosial dan mengatur keadilan sesuai dengan hukum yang telah Engkau wahyukan". Inilah yang sebenarnya dimaksudkan ayat tersebut. Menurut al-Maudûdî bahwa reformasi yang hendak diwujudkan Islam tidak dapat dilaksanakan hanya dengan ibadah saja. Kekuasaan politik sangatlah penting untuk pencapaiannya. Dan karena perjuangan untuk meraih kendali atas organ-organ negara, jika digerakkan oleh niat untuk menegakkan dîn dan syari'at Islam, serta untuk menegakkan perintah-perintah Islam, tidak hanya diperkenankan melainkan secara positif diperlukan dan oleh karenanya diwajibkan. Menurutnya salah besar jika orang menganggap upaya ini hanya sebagai alat atau hanya bersifat duniawi atau mencap sebagai "haus kekuasaan". Jika seseorang berjuang demi kemuliaan pribadinya dan berniat meraih kekuasaan demi kepentingan-kepentingan pribadi, maka orang inilah yang justru patut dikutuk dan dianggap tidak islami. Tetapi jika kekuasaan yang dicari ini adalah untuk menegakkan dîn Allah, maka tentulah ia merupakan tindakan ilahiyah dan termasuk perbuatan saleh, sama sekali tidak perlu dicampuradukkan dengan kehausan dan kekuasaan. ${ }^{12}$

Jika dikaji lebih lanjut perjalanan pemikiran al-Maudûdî, maka akan menjadi semakin menarik. Al-Maudûdî yang pada

11.Abû al-A'lâ al-Maudûdî, Tafhîm Al-Qur'ân (The Meaning of The Qur'an), ter. Ch. Muhammad Akbar, vol. viii (Lahore: Islamic Publications, 1989), 57. 12Al-Maudûdî, Tafhîm..., 638. 
awalnya menolak pendirian negara Islam yang digagas oleh Liga Muslim ketika Pakistan memisahkan diri dari India, akan tetapi kemudian ia berpaling menjadi seorang pejuang negara Islam. Apa sebenarnya yang diinginkan oleh al-Maudûdî? Jika kita mencermati kata-katanya yang dituangkan dalam majalah Tarjumân al-Qur'ân perihal penolakannya terhadap gagasan yang disuarakan oleh Liga Muslim, nampaknya al-Maudûdî bukan tidak setuju akan pentingnya sebuah pendirian negara Islam, hanya ia tidak menyepakati cara-cara yang digunakan oleh Liga Muslim dalam mengusung gagasan pendirian negara Islam. Menurutnya, Liga Muslim yang mengeluarkan resolusi pembentukan negara Pakistan itu, menurut analisis al-Maudûdî sebenarnya bukan "Partai Islam" akan tetapi berbentuk "Partai Sekular".

Hal ini terlihat dari ideologi yang dipakai oleh Liga Muslim yakni mencantumkan "nasionalisme muslim" sebagai asasnya, bukan Islam itu sendiri. Dari sini nampaknya al-Maudûdî merasa ragu akan kesungguhan dan orientasi Liga Muslim dalam menyuarakan pentingnya negara Islam. Tidak hanya itu, alMaudûdî juga merasa ragu akan para elite pemimpin Liga Muslim yang menurutnya tidak menjalankan ajaran Islam dengan sebenar-benarnya. Karena alasan inilah menurut hemat penulis kenapa al-Maudûdî tidak sependapat dengan Liga Muslim yang dimotori oleh Ali Jinnah dan bukan penolakan atas gagasan pendirian negara Islam seperti yang selama ini dianggap oleh beberapa peneliti pemikiran al-Maudûdî.

Uraian di atas menegaskan bahwa pendirian sebuah negara Islam bagi al-Maudûdî haruslah didasari oleh pondasi Islami. Tidak hanya itu, aplikasi kesalehan dalam dunia nyata bagi mereka yang menyuarakan gagasan negara Islam juga harus tercermin. Dalam sejarahnya, al-Maudûdî tidak pernah menolak rencana pendirian negara Islam, justru sebaliknya, ia adalah sosok yang sangat gigih di dalam menyuarakan arti penting pembentukan negara Islam, terlebih setelah Jamâ'ati Islâmî 
secara resmi menjadi partai politik yang mengusung gagasangagasan al-Maudûdî.

Menurut al-Maudûdî, hanya amîr satu-satunya yang berhak menerima ketaatan dan kesetiaan rakyat, dan bahwa rakyat mendelegasikan sepenuhnya hak mereka untuk mengambil keputusan mengenai semua masalah yang berkaitan dengan hajat hidup mereka. Kedudukan amîr menurut al-Maudûdî sangat berbeda dengan raja atau ratu seperti di negara Inggris atau presiden, atau bahkan Perdana Menteri. Dalam konsepnya, alMaudûdî tidak menyebutkan bentuk pemerintahan seperti apa, ia hanya mengatakan bahwa bentuk pemerintahan yang digagas olehnya bukan seperti bentuk pemerintahan modern. Ia hanya mengatakan bahwa bentuk konsep kedaulatan Tuhan atau dalam istilah modern dikenal dengan teo-demokrasi yang tepat diterapkan jika negara Islam kelak terwujud di Pakistan.

Melihat bagaimana seharusnya perilaku seorang khalifah yang dirancang oleh al-Maudûdî, bisa dikatakan bahwa bentuk pemerintahan harus seperti pada masa Khalîfah al-Râsyidîn. Akan tetapi jika kita lihat pada waktu perumusan konstitusi dalam Dewan Konstitusi tahun 1956, rumusan itu mencantumkan nama resmi negara dengan "Republik Islam Pakistan". Hasil konstitusi itu ternyata mendapat dukungan dari al-Maudûdî. Meskipun al-Maudûdî dalam konsepnya menginginkan bentuk negara seperti Khalîfah al-Râsyidîn, akan tetapi ia menyetujui bentuk pemerintahan negara republik.

Posisi amîr dalam negara Islam menurut al-Maudûdî memegang kekuasaan tertinggi. Beban yang diemban oleh seorang amî adalah bukan saja sebagai pemimpin eksekutif, tetapi juga ia harus bertanggung jawab terhadap urusan keagamaan. Argumentasi yang dibangun oleh al-Maudûdî adalah tradisi yang pernah dilakukan oleh Nabi saw. dan masa Khulafâ' al-Râsyidîn, yakni amîr berkewajiban menjadi imam shalat fardlu' lima waktu di masjid besar di ibu kota negara dan menjadi khâtib di setiap shalat jum'at di masjid tersebut". 
Dalam pemilihan seorang amîr, al-Maudûdî merekomendasikan dipilih dari mereka yang bertakwa, hal ini sesuai dengan firman Allah swt. Dalam Qs. al- $\underline{H u j u r a ̂ t ~(49): ~} 13$. Ayat ini menjelaskan bahwa dalam pencalonan kepala negara (imârah) dipilih dari seorang muslim yang biografi, perangai, dan akhlaknya dipercaya masyarakat. Jika masyarakat telah sepakat maka calon baru diperbolehkan memimpin umat. Selanjutnya, rakyat wajib mematuhi segala perundang-undangannya. Dalam masalah pelaksanaan hukum, secara total bersandar pada pemimpin (khaliffah) selama khalifah itu masih berkomitmen kepada syari'at yang digariskan oleh al-Qur'an dan hadis. ${ }^{13}$

Mencermati pemikiran al-Maudûdî yang mengatakan bahwa tugas seorang amîr tidak hanya mengurusi pemerintahan, akan tetapi juga menjadi panutan dalam hal keagamaan membuat pola pemikirannya tidak jauh berbeda dengan para pemikir Islam pada masa klasik yang mengatakan bahwa Islam adalah sebuah agama yang komprehensif, yang tidak hanya mengatur hal-hal yang terkait dengan ibadah, akan tetapi mencakup seluruh aspek kehidupan, termasuk aspek politik. Pembahasan bagaimana mengatur sebuah pola kehidupan di dunia dengan baik termasuk di dalamnya tentang kenegaraan sudah dijelaskan dalam alQur'an dan hadis Nabi saw., manusia tinggal mencontoh bagaimana pola kehidupan Nabi saw. di dalam mengatur umatnya, karena posisi Nabi saw. tidak hanya sebagai pengemban ajaran Allah, melainkan juga sebagai teladan dan pemimpin bagi umatnya di dalam mengatur kehidupan.

Dalam pemikiran al-Maudûdî, seorang amîr berada pada posisi lembaga eksekutif. Pemikirannya ini berbeda dengan mekanisme struktur negara yang berkembang di dunia modern. Menurutnya, model seperti inilah yang membedakan antara sistem negara yang diterapkan di dunia Barat dengan model

13Abû al-A'lâ al-Maudûdî, Politik Alternatif; Suatu Perspektif Islam, ter. Muhammad Nurhakim (Jakarta: Gema Insani Press, 1991), 67-8. 
negara Islam. ${ }^{14}$ Munculnya konsep al-Maudûdî seperti ini didasari oleh pemahamannya bahwa seorang amîr tidak hanya bertanggung jawab terhadap pemerintahan yang dipimpinnya, melainkan juga terhadap agamanya, karena ia berfungsi sebagai wakil Tuhan di bumi.

Dalam struktur negara Islam menurutnya, ada yang disebut

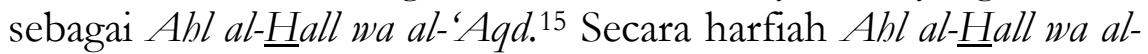
'Aqd (badan legislatif) berarti orang yang dapat memutuskan dan mengikat. Sedangkan para ahli fiqh siyâsah mendefinisikan $A b l$ al- $\underline{H}$ all wa al-'Aqd sebagai orang yang memiliki kewenangan untuk memutuskan dan menentukan sesuatu atas nama umat (warga negara). Dengan demikian Abl al- $\underline{H}$ all wa al-'Aqd adalah lembaga perwakilan yang menampung dan menyalurkan aspirasi atau suara masyarakat. Al-Mâwardî menyebut lembaga ini dengan Abl al-Ikhtiyârî, ${ }^{16}$ sedangkan Ibn Taymîyah menyebutnya dengan $A b l$ al-Syûrâ atau Abl al-Ijmâ, sedangkan al-Baghdâdî menyebutnya dengan Abl al-Ijtihâd. ${ }^{17}$

Prosedur pembentukan badan ini menurut al-Maudûdî sama dengan prosedur pemilihan umum yang dipraktikkan zaman modern, sepanjang ia dipraktikan dengan jujur dan bebas dari unsur kecurangan. Mekanisme pencalonan untuk menjadi

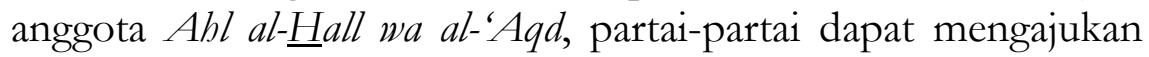
para calon dalam pemilihan umum. Menurut al-Maudûdî, meskipun para calon anggota badan Abl al- $\underline{H}$ all wa al-'Aqd dari berbagai unsur partai, akan tetapi ketika ia sudah menduduki

${ }^{14} \mathrm{Abû}$ al-A'lâ Al-Maudûdî, Hukum dan Konstitusi; Sistem Politik Islam, ter. Asep Hikmat (Bandung: Mizan, 1990), 347.

15 Abl al- Hall wa al-'Aqd secara harfiyah berarti orang-orang yang dapat memutuskan atau mengikat. Para ahli fiqh politik merumuskan pengertian Abl al- $\underline{H}$ all wa al-'Aqd sebagai orang yang memiliki kewenangan untuk memutuskan dan menentukan sesuatu atas nama umat (warga negara).

16Al-Mâwardî, Al-A $\underline{b} k$ âm al-Sulthâniyyah (Mesir: Mathba'ah al-Watan, $1298 \mathrm{H}), 5$.

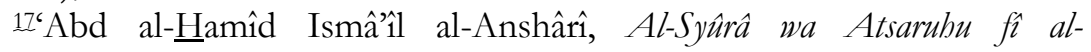
Dimuqrathiyah (Kairo: Mathba'ah al-Salafiyah, 1980), 233-4. 
anggota jabatan di badan Abl al- $\underline{H}$ all wa al-'Aqd secara otomatis harus mengikuti dan mendukung sang amîr. ${ }^{18}$

Dalam konsepsi al-Maudûdî, Abl al- $\underline{H}$ all wa al-'Aqd tidaklah sama dengan konsep yang ada dalam teori Trias Politica. Konsepsi Abl al- $\underline{H}$ all wa al-'Aqd menurutnya lebih dekat pada Majlis Syûrâ. Fungsi utama $A b l$ al- $\underline{H}$ all wa al-'Aqd menurutnya; pertama, adalah sebagai lembaga penengah dan pemberi fatwa. Kedua, jika terdapat pedoman-pedoman yang jelas dari Tuhan dan Rasulnya, meskipun lembaga legislatif tidak dapat mengubah atau menggantinya, maka hanya lembaga legislatiflah yang mempunyai kompetensi untuk menegakkannya dalam suasana dan bentuk pasal, serta menggunakan definisi-definisi yang relevan serta rincian-rinciannya. Ketiga, jika pedoman al-Qur'an dan sunnah mempunyai kemungkinan interpretasi lebih dari satu, maka lembaga legislatiflah yang berhak memutuskan penafsiran mana yang harus ditempatkan dalam kitab UndangUndang Dasar. Keempat, jika ada isyarat yang jelas dalam alQur'an dan sunnah, fungsi lembaga legislatif ini adalah untuk menegakkan hukum-hukum yang berkaitan dengan masalah yang sama yang tentunya harus sesuai dengan hukum Islam. Kelima, jika al-Qur'an dan sunnah tidak memberikan pedoman atau masalah itu tidak ada dalam konvensi Khulafâ' al-Râsyidîn, maka kita harus mengartikan bahwa Tuhan telah membiarkan kita bebas melakukan legislasi mengenai masalah ini menurut apa yang terbaik. ${ }^{19}$

Selengkapnya tentang struktur negara Islam dalam versi alMaudûdî dapat dirumuskan sebagaimana bagan di bawah ini:

18Al-Maudûdî, The Islamic Law..., 230.

19 Ibid., 246. 


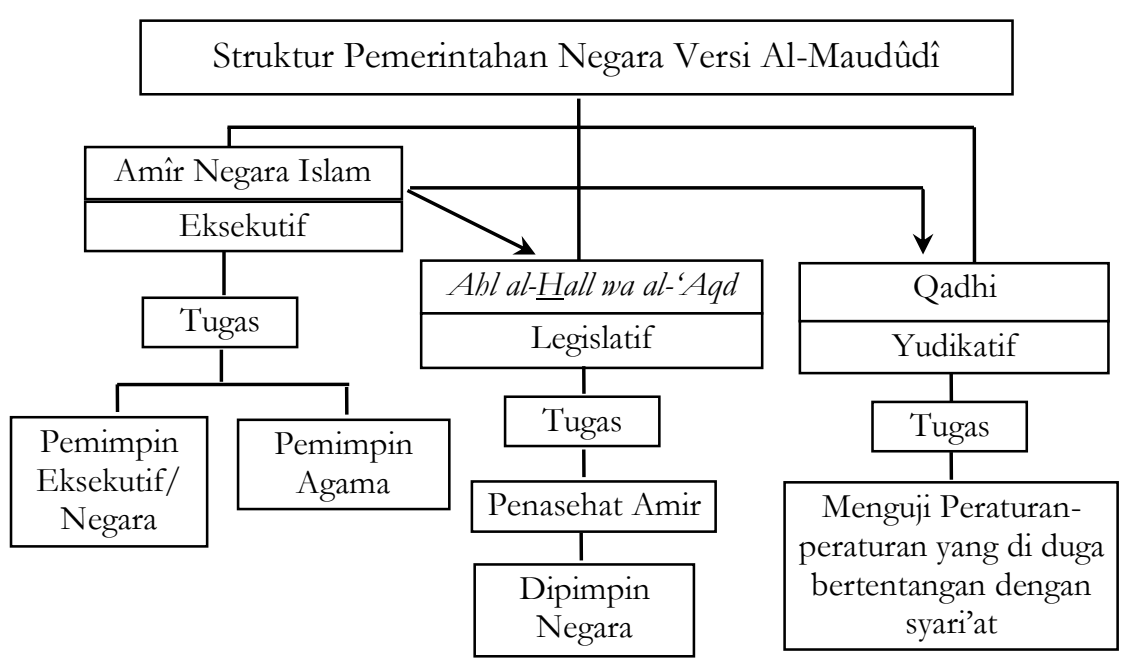

Dalam hal kriteria pemimpin negara dalam Islam, al-Maudûdî mensyaratkan seorang khalifah sebagai berikut: Pertama, ia harus seorang muslim, kriteria ini menurutnya sesuai dengan firman Allah dalam Qs. al-Nisâ' (4): 59. Dengan pemahaman ayat ini, alMaudûdî tidak memberikan hak kepada non-muslim untuk menjadi kepala negara yang memimpin umat Islam. Kedua, ia haruslah seorang laki-laki, syarat ini pun dijelaskan sebagaimana dalam Qs. al-Nisâ' (4): 34. Ketiga, seorang pemimpin negara haruslah dalam keadaan waras dan dewasa. Syarat ini dijelaskan dalam Qs. al-Nisâ' (4): 5. Keempat, seorang pemimpin negara harus merupakan warga dari negara Islam. Syarat keempat yang diacu oleh al-Maudûdî berdasarkan keterangan dari Qs. al-Anfâl (8): 72 .

Jika dilakukan analisis atas persyaratan yang diajukan oleh alMaudûdî, persyaratan yang keempat ini hampir sama dengan persyaratan nomor pertama di atas, ia tidak memberikan hak kepada warga non-muslim untuk memimpin negara Islam meskipun ia mempunyai kualitas sebagai seorang pemimpin. Jika kita bandingkan dengan pendapat al-Maudûdî sebelumnya yang mengatakan bahwa masing-masing manusia mempunyai peluang 
dan kedudukan yang sama dan tidak ada perbedaan untuk menjadi seorang khalîfah di muka bumi ini, maka terlihat bahwa kata-kata al-Maudûdî ini tidak konsisten atau bertolak belakang dengan kata-kata sebelumnya. Di samping syarat-syarat di atas, al-Maudûdî juga memberikan syarat-syarat seorang pemimpin negara yang harus dipilih dan kriterianya merujuk pada beberapa ayat-ayat al-Qur'an. Di antara syarat tersebut adalah bersifat amanat, adil, bertakwa, dan berilmu luas.

Menarik untuk dicermati ketentuan yang ditetapkan oleh alMaudûdî perihal syarat-syarat kepala negara, yaitu tidak dimasukkannya keturunan Quraisy sebagai syarat menjadi seorang pemimpin negara meskipun telah jelas dinyatakan dalam hadis Nabi saw. ${ }^{20}$ Dalam karyanya al-Maudûdî tidak memberikan

20Ada beberapa hadis Nabi saw. yang menceritakan tentang keutamaan suku Quraisy. Dari hadis Nabi saw. ini kemudian para ulama merumuskan bahwa salah satu syarat seorang imam adalah ia dari suku Quraisy. Di antara hadis itu adalah sebagai berikut: "Dalam masalah ini, manusia selalu menuruti suku Quraisy; yang muslim mengikuti yang muslim, dan yang kafir mengikuti yang kafir" (HR. Bukhari dan Muslim). Ada juga hadis yang berbunyi: "Masalah ini selalu berada di tangan suku Quraisy. Siapa pun yang menentangnya, wajahnya akan ditampar oleh Allah, selama suku Quraisy melaksanakan ajaran Islam" (HR. Bukhari). Dari hadis ini kemudian muncul pertanyaan, apakah jabatan seorang pemimpin mesti dijabat oleh orang Quraisy, apakah tidak boleh orang lain? Apakah hadis itu mengandung makna perintah yang harus dilaksanakan ataukah hanya sekedar berita tentang keutamaan suku Quraisy dibandingkan dengan suku-suku lainnya pada waktu itu? Kalau kita memahami sejarah Arab saat itu, ada beberapa alasan mengapa suku Quraisy dianggap sebagai suku yang paling utama, yakni suku Quraisy pada waktu Islam lahir telah menempati kedudukan yang terhormat di tanah Arab. Menurut hemat penulis, hadis-hadis yang berisi keutamaan suku Quraisy di atas bukanlah sebuah perintah yang wajib dilaksanakan, akan tetapi sebuah berita tentang keutamaan suku Quraisy. Hal ini bisa dipahami dari pernyataan “....selama mereka menegakkan agama Islam". Hadis di atas bisa dibantah dengan hadis Nabi saw. yang lain "Abû Dzar berkata: kekasihku (Nabi saw.) berwasiat kepadaku agar aku patuh dan taat walau orang yang menjadi pemimpin adalah seorang hamba hitam yang jelek" (HR. Bukhari dan Muslim). Dari hadis ini semakin jelaslah 
alasan mengapa ia tidak mencantumkan syarat kepala negara dari suku Quraisy padahal syarat tersebut telah disepakati oleh mayoritas ulama Sunni. Di sini nampaknya al-Maudûdî menyadari bahwa persyaratan harus dari suku Quraisy sudah tidak realistis lagi di masa modern saat ini. Di samping itu tidak begitu penting untuk diterapkan pada masanya mengingat sudah begitu jauh jarak waktu yang memisahkan. Dengan demikian sangatlah sulit untuk mendeteksi apakah ia betul berasal dari suku Quraisy atau bukan. Alasan lain adalah tidak pastinya di setiap negara termasuk di Pakistan sendiri terdapat suku Quraisy mengingat saat ini umat Islam tersebar di seluruh dunia, bukan hanya di Arab, tambahan lagi mengingat alasan yang diutarakan oleh Ibn Taymiyah di atas, yakni permasalahan keharusan dari suku Quraisy termasuk permasalahan yang masih diperdebatkan. Pemikiran al-Maudûdî tentang tidak dimasukannya syarat pemimpin harus dari suku Quraisy menjadikan ia seorang intelektual Islam pertama dari kalangan pemikiran Islam modern yang secara tegas menolak ketentuan syarat dari suku Quraisy sebagaimana yang dirumuskan oleh para ulama klasik.

Sisi menarik lain yang diutarakan oleh al-Maudûdî adalah perihal syarat jenis kelamin, yakni harus laki-laki yang berhak menjadi pemimpin negara. Persyaratan ini sama dengan apa yang disampaikan oleh al-Ghazâlî, dan pernah diberlakukan oleh alMaudûdî ketika pemilihan seorang amîr dalam Jamâ'ati Islâmî. Dari sini terlihat bahwa status seorang harus laki-laki di dalam syarat menjadi pemimpin adalah syarat yang tidak bisa ditawartawar karena telah jelas dikatakan dalam Qs. al-Nisâ' (4): 34.

Namun, jika kita mengutip pendapat al-Maudûdî sebelumnya bahwa hak khalifah adalah milik semua manusia, apa pun bangsanya, karena dalam Islam tidak ada sistem diskriminasi, baik itu dari segi keturunan, status sosial, maupun latar belakang

bahwa hadis yang berisi keutamaan suku Quraisy tersebut hanya sebuah cerita, berita, atau pemberitahuan dan bukanlah sebuah kewajiban yang mesti diterapkan. 
ekonomi. Ketika mensyaratkan seorang pemimpin haruslah lakilaki, maka menurut hemat penulis al-Maudûdî lagi-lagi terlihat tidak konsisten dalam berpendapat. Bukankah al-Qur'an sendiri mengatakan dengan tegas bahwa tidak ada yang lebih baik di mata Allah kecuali mereka yang bertakwa (laki-laki dan perempuan). Tidak hanya itu, dalam kehidupan politik, sosial, budaya, dan ekonomi, laki-laki dan perempuan masing-masing memikul tanggung jawab yang sama, bergandengan tangan, dan bahu membahu sebagai mitra sejajar seperti ditegaskan dalam Qs. al-Tawbah (9): 71.

Pendapat al-Maudûdî tentang pelarangan perempuan menjadi pemimpin negara dengan argumentasi teks al-Qur'an, semakin membuktikan tidak konsistennya dalam berfikir ketika ia pada pemilihan umum Pakistan tahun 1964 terlihat mendukung seorang calon presiden wanita, yakni Miss Fatimah Jinnah dalam melawan Jenderal Ayyub Khan. Dalam sejarah perkembangan politik Pakistan, nama Jenderal Ayyub Khan adalah salah seorang tokoh yang cukup berpengaruh dan memberikan warna tersendiri di Pakistan. Ketika pada pemilu tahun 1958, partai Jamâ'ati Islâmî yang dikomandoi oleh alMaudûdî mempunyai peluang besar untuk memenangkan pemilu tersebut, ternyata dianggap membahayakan, sehingga sebelum pemilu dilaksanakan, tentara Pakistan yang dikomandoi oleh Jenderal Ayyub Khan mengambil alih komando negara (kudeta tak berdarah). Presiden Pakistan saat itu Iskandar Mirza mengeluarkan dekrit membubarkan Parlemen dan seluruh partai yang ada di negara itu, termasuk di dalamnya partai Jamâ'ati Islâmî pada tanggal 3 September 1958. ${ }^{21}$ Setelah empat tahun pembubaran partai, tepatnya pada tahun 1962, ketika Jenderal Ayyub Khan menjadi Presiden Pakistan, partai Jamâ'ati Islâmî dihidupkan kembali. Tidak hanya itu, ia pun menghapuskan

\footnotetext{
${ }_{21}^{21}$ Khalid B. Sayed, “The Jamâ'ati Islâmî Movement in Pakistan”, Pacific Affairs, vol. 30, 1958, 93.
} 
undang-undang darurat militer dan mengizinkan pembentukan kembali partai-partai politik lainnya.

Melihat peta politik Pakistan saat itu, kemudian dikaitkan dengan dukungan al-Maudûdî terhadap salah seorang calon presiden wanita, yakni Miss Fatimah Jinnah, nampaknya alMaudûdî begitu kecewa terhadap Jenderal Ayyub Khan yang melakukan kudeta terhadap pemerintah yang sah dan pada akhirnya menyebabkan pembubaran partai Jamâ'ati Islâmî oleh pemerintah itu sendiri. Dengan dukungan al-Maudûdî dan Jamâ'ati Islâmî, calon presiden Miss Fatimah Jinnah diharapkan dapat menyaingi dan mengalahkan Jenderal Ayyub Khan yang sedang berkuasa saat itu, yang tentunya sebagai imbalan atas dukungannya, partai Jamâ'ati Islâmî akan menancapkan pengaruhnya di Pakistan. Dari sini bisa diambil pelajaran bahwa meskipun pada awalnya al-Maudûdî menolak kepemimpinan kaum perempuan, akan tetapi ketika realita politik merugikan diri dan partainya, maka ia dengan terang-terangan menyalahi atau "menjual" komitmen sebelumnya, bahwa kaum perempuan tidak berhak untuk duduk dalam posisi pemimpin, terlebih pemimpin negara dengan alasan bertentangan dengan petunjuk kitab suci al-Qur'an.

\section{Menakar Relevansi Gagasan Abû al-A'lâ al-Maudûdî}

Ada banyak sebab mengapa wacana negara Islam ataupun khilâfah islâmiyah ini mulai menyeruak kembali. Beberapa faktornya adalah; pertama, karena tekanan rezim politik yang berkuasa yang hidup di bawah bayang-bayang kepentingan Barat. Kelompok Islam terentu tidak mendapat hak kebebasan berpendapat. Kedua, kegagalan-kegagalan ideologi sekular rezim yang berkuasa, dengan isu-isu modernitas, ternyata tidak kunjung berhasil mengembalikan umat Islam ke dalam kondisi yang mapan, bahkan semakin terpuruk baik itu dari sudut ekonomi, politik, dan budaya, bahkan cenderung mendangkalkan paham agama. Kehadiran fundamentalisme atau 
radikalisme agama dianggap sebagai alternatif ideologis satusatunya pilihan yang nyata bagi umat Islam yang diharapkan dapat mengembalikan Islam kembali pada masa kejayaannya dengan berpedoman kepada al-Qur'an dan tuntunan Nabi saw. (hadis). Bagi kelompok ini, salah satu cara untuk mengembalikan kejayaan Islam seperti masa keemasannya dahulu adalah membentuk atau mewujudkan apa yang dinamakan negara Islam sebagai pelaksana syariat Islam secara total. Alasan yang dipegang oleh kelompok ini adalah karena Islam merupakan agama sekaligus negara (al-Islâm huwa al-dîn wa al-dawlab).

Terlepas dari perdebatan pro-kontra di atas, yang pasti bahwa agama dan politik merupakan dua hal yang tak dapat dipisah-pisahkan dalam Islam, keduanya saling berkaitan. ${ }^{22}$ Dalam al-Qur'an dan penjelasan Nabi saw. sendiri, meskipun tidak secara jelas diungkapkan bagaimana bentuk pemerintahan yang paling tepat dalam Islam, akan tetapi keduanya memberikan ajaran tata nilai dan etika bagaimana mengatur sebuah kehidupan bermasyarakat maupun bernegara. Nabi Muhammad sendiri, meskipun tidak menyatakan secara tegas sebagai pemimpin negara, akan tetapi dia telah menjadikan negara sebagai sebuah alat bagi umat Islam untuk menyebarkan dan mengembangkan agama.

Untuk menanggapi pandangan al-Maudûdî tentang keterkaitan antara agama dengan negara, maka ada dua opsi sebagai pijakan analisis; Pertama, secara ontologis-substansiil, pandangan al-Maududi tentang pentingnya pembentukan negara dan tujuannya adalah bisa diterima. Dia secara lebih lugas menyatakan bahwa Islam dengan al-Qur'an tidak hanya berisi

22Di antara cendekiawan muslim yang mempunyai pendapat seperti ini adalah Fazlur Rahman ia mengatakan bahwa "antara agama dan politik tidak dapat dipisahkan". Pendapat ini dapat dilihat dalam Fazlur Rahman, "Islam and Political Action: Politics in the Service of Religion", dalam Cities of Gods: Faith, Politics and Pluralism in Judaism, Christianity and Islam, ed. Nige Bigger dkk. (New York: Greenwood Press, 1986), 154. 
pesan moral, ibadah dan etika saja, akan tetapi di dalamnya juga berisi tuntunan-tuntunan dalam bidang sosial, ekonomi, dan politik termasuk di dalamnya perihal aturan hukum negara dan institusi kenegaraan. ${ }^{23}$ Segala macam aturan yang terkandung dalam al-Qur'an tersebut haruslah direalisasikan dalam dunia nyata, dan salah satu caranya adalah dengan mendirikan negara Islam yang berbasiskan hukum Islam secara penuh. Menurutnya, kita harus menegakkan hukum Ilahi berdampingan dengannya dan menjadikan syari'at sebagai undang-undang negara. Ia menambahkan jika langkah ini tidak dilakukan, maka kita tidak bisa menegakkan agama secara sempurna akan tetapi sebagian saja dari agama, dan jika hal ini terjadi, maka hal ini tidak lain adalah bentuk penolakan atas agama itu sendiri. ${ }^{24}$

Menurut al-Maudûdî bahwa tujuan negara yang dikonsepsikan oleh al-Qur'an tidaklah negatif, tetapi positif. Tujuan negara tidak hanya mencegah rakyat untuk saling memeras melainkan untuk melindungi kebebasan mereka dan melindungi seluruh bangsanya dari invasi asing. Negara bertujuan untuk mengembangkan sistem keadilan sosial yang berkeseimbangan yang telah diketengahkan Allah dalam alQur'an. Untuk merealisasikan tujuan ini, maka menurut alMaudûdî kekuasaan politik akan digunakan demi kepentingan itu dan bilamana diperlukan, semua sarana propaganda dan persuasif damai akan digunakan, pendidikan moral rakyat juga akan dilaksanakan, dan pengaruh sosial maupun pendapat umum akan dijinakkan. ${ }^{25}$

Uraian al-Maudûdî di atas dapat dipahami bahwa tujuan pembentukan negara menurutnya adalah menegakkan keadilan dalam kehidupan manusia dan menghentikan kedzaliman serta menghancurkan kesewenang-wenangan seperti yang telah banyak disebutkan oleh Allah dalam al-Qur'an. Tujuan

\footnotetext{
${ }_{23}^{23}$ l-Maudûdî, The Islamic Law...,186.

24 Ibid., 187.

25Al-Maudûdî, Tafhîm..., 31-4.
} 
pembentukan Negara Islam menurut al-Maudûdî juga

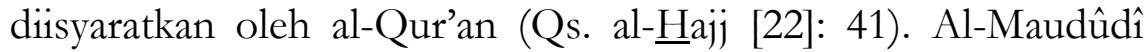
menegaskan bahwa kejahatan yang tidak dapat dimusnahkan melalui ajaran-ajaran al-Qur'an membutuhkan kekuasaan memaksa dari pihak negara untuk melakukan pembasmian. ${ }^{26}$ Ini berarti bahwa tujuan negara dalam Islam menurutnya adalah untuk mengukuhkan sekaligus menegakkan dan melaksanakan kekuasaannya dengan segenap sumberdaya yang ada untuk menciptakan kehidupan yang lebih baik bagi perbaikan kehidupan manusia.

Kedua, secara aksiologis-operasional, mewujudkan gagasan pandangan al-Maudûdî seperti yang dia konsepsikan tampaknya sulit diwujudkan. Tampaknya al-Maudûdî sangat realistis di dalam memperjuangkan gagasannya, karena ia sadar bahwa perjuangan yang hanya mengandalkan dari segi gagasan-gagasan secara individual dan teoritis tanpa didukung oleh pengalaman nyata dan didukung oleh golongan terdidik yang punya peduli dalam mendirikan negara Islam akan sia-sia dan sulit terealisasi dengan cepat di Pakistan. Tidak hanya itu, nampaknya alMaudûdî juga menyadari akan begitu kuatnya pengaruh para intelektual Islam yang berada di lingkungan Liga Muslim, yang menurutnya berideologi sekular dan membahayakan negara Pakistan di kemudian hari. Karena alasan inilah maka alMaudûdî merasa penting untuk membuat lembaga atau organisasi tandingan dari Liga Muslim di dalam menyuarakan aspirasi umat Islam Pakistan, khususnya terkait dengan pembentukan negara Islam. Akan tetapi sangat disayangkan, cita-cita al-Maudûdî tidak berjalan sesuai dengan rencana. Hal ini terjadi karena partai Jamâ'ati Islâmî cenderung lebih eksklusif dan menetapkan syarat-syarat keanggotaan yang begitu ketat dan sulit untuk diikuti oleh masyarakat luas apalagi mereka yang

26Al-Maudûdî, Islamic..., 216-7. 
awam agama. Karena alasan inilah maka partai Jamâ'ati Islâmî semenjak didirikannya tak pernah memenangi pemilu di Pakistan, hanya pada masa rezim Zia-ul Haq, program partai ini sedikit terakomodasi.

Terkait dengan sistem khilâfah, menurut penulis, ia merupakan ide yang sulit diterapkan. Gagasan khilâfah pada masa modern kontemporer menyerukan pembentukan kekuasaan politik tunggal bagi seluruh umat Islam di muka bumi; sebuah gagasan yang dapat dipertanyakan kelayakan dan keberlangsungannya (viability). Jika umat Islam boleh jujur kepada diri sendiri, kesatuan semacam itu tidak pernah terwujud, bahkan sebelum berakhirnya kekuasaan al-Khulafâ' al-Râsyidûn. Kesatuan hanya terwujud pada masa Abû Bakar dan Umar bin Khattâb. Tetapi sejak masa khalifah ketiga, Utsmân bin 'Affân, terjadi pertikaian dengan 'Ali bin Abi Thâlib-lalu menjadi khalifah keempat. Sejak itu, persatuan umat Islam di bawah satu kekuasaan politik tunggal lebih merupakan imajinasi yang jauh, untuk tidak mengatakan sulit terwujud.

Abû A'lâ al-Maudûdî, yang merumuskan khilâfah secara lebih komprehensif menyadari bahwa tidak mungkinnya mewujudkan khilâfah universal dan menyerah kepada realitas negara-bangsa (nation-state). Ia menerima kehadiran negara-bangsa Pakistan pascapartisi Anak Benua India pada tahun 1947, lalu mendirikan parpol Jamâ'ati-Islâmî untuk mewujudkan cita-citanya mencapai khilâfah. Al-Maudûdî dan Jamâ'ati-Islâmî terlibat dalam pergulatan politik nasional Pakistan yang kompleks, sampai terlihat seolah-olah melupakan gagasan dan cita khilafah-nya.

Pengalaman al-Maudûdî itu setidaknya menunjukkan dua kontradiksi. Pertama, khilâfah tidak mungkin dicapai melalui negara-bangsa. Kedua, negara bangsa yang ada pada dasarnya menerapkan sistem demokrasi modern. Dan khilâfah tidak kompatibel dengan demokrasi yang bersandar pada vox populi vox dei (suara rakyat adalah suara Tuhan), sementara khilâfah yang berdasar pada vox dei vox populi (suara Tuhan adalah suara rakyat). 
Realitas politik yang begitu kompleks membuat al-Maudûdî mengkompromikan cita khilâfah-nya dengan negara-bangsa yang menerapkan sistem demokrasi modern.

\section{Catatan Akhir}

Sebagai seorang tokoh pemikiran Islam, pandangan alMaudûdî tentang konsep negara Islam dapat dipahami bahwa ia sebenarnya tidak pernah menolak mendirikan sebuah negara Islam, meskipun pada masa hidupnya ia pernah mengeluarkan pernyataan penolakan terhadap gagasan pendirian negara Islam yang diajukan oleh Liga Muslim yang dituangkan dalam Tarjumân Al-Qur'ân. Sebaliknya, al-Maudûdî adalah pejuang yang gigih dalam mewujudkan sebuah negara Islam yang tentunya dengan berlandaskan aturan al-Qur'an dan Hadits. Al-Maudûdî pada dasarnya menyetujui apapun bentuk atau model sebuah negara, yang penting baginya adalah jenis kedaulatan yang dianut harus menganut kedaulatan Tuhan (teo-demokrasi) sebagai ciri sebuah negara dikatakan islami dan tidak seperti model negara republik pada umumnya yang berkembang di dunia Barat yang memakai sistem kedaulatan rakyat atau demokrasi.

Al-Maudûdî adalah seorang pejuang negara Islam yang gigih. Namun sayangnya, dari beberapa pemikiran yang diutarakan alMaudûdî tentang konsep negara Islam ini ditemukan ada beberapa hal terkait dengan pemikirannya yang tidak konsisten, hal itu karena berhubungan dengan kepentingan politik sesaat demi mewujudkan penerapan syari'at Islam secara utuh di Pakistan. Dengan demikian, kita tidak dapat menjadikan pandangan seseorang sebagai sesuatu yang harus dipuja karena kadangkala gagasan tersebut oleh yang bersangkutan juga tidak dilaksanakan secara konsekuen. 


\section{Daftar Pustaka}

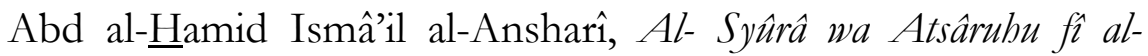
Dimuqrâthiyah (Kairo: Mathba'ah al-Salafiyah, 1980).

Abd al-'Athi Muhammad Ahmad, Al-Fiker al-Siyâsî li al-Imâm

Muhammad 'Abdub (Mesir: Al-Haiat al-Mishriyyat al-'Ammat li al-Kitâb, 1978).

Abû al-A'lâ Al-Maudûdî, al-Aḅkâm as-Sulthâniyyah (Mesir: Matba'ah al-Watan, $1298 \mathrm{H})$.

, Politik Alternatif; Suatu Perspektif Islam, ter.

Muhammad Nurhakim (Jakarta: Gema Insani Press, 1991). , Hukum dan Konstitusi; Sistem Politik Islam ter. Asep

Hikmat (Bandung: Mizan, 1990).

, Jamâ'at Islâmî, us ka Maqsad, Tarikh, Awr la Laibi

aml "The Jamâ'at Islâmî, Its Aim, History and Programme"

(Lahore: Markazi Maktabah Jamâ’at Islâmî, 1953).

, Khilâfah dan Kerajaan; Evaluasi Kritis atas Sejarah

Pemerintahan Islam, ter. Muhammad al-Baqir (Bandung:

Mizan, 1996).

1956).

, Rights Non-Muslim in Islamic State (Lahore: t.p. , Tafhîm Al-Qur'ân (The Meaning of The Quran), ter.

'Abdul 'Aziz Kamal (Lahore: Islamic Publications, 1989).

Abû Hasan al-Mâwardî, Adab al-Dunyâ wa al-Dîn tahqî̀; Abd al-

Satar Ahmad Faraj (Beirut: Alam Kutub, t.t.).

Ahmad Idris, Ab̂̀ al-A'lâ al-Maudûdî; Sabafatun min Hayâtỉ wa Jihâdih (Kairo; al-Mukhtar al-Islami, 1979).

Alî 'Abd al-Razîq, Al-Islâm wa Ushûl al- $\underline{H}$ ukm (Kairo: al-Qâhirah, 1925).

Ali Rahmena, Para Perintis Zaman Baru Islam (Bandung: Mizan, 1996).

Azyumardi Azra, "Jihad dan Revolusi Islam; Pandangan AlMaudûdî", dalam Pergolakan Politik Islam; Dari 
Fundamentalisme, Modernisme Hingga Post-Modernisme (Jakarta: Paramadina, 1996).

Charlie J. Adams, "Maudûdî dan Negara Islam", dalam Dinamika Kebangunan Islam; Watak, Proses, dan Tantangan, ed. John L. Esposito (Jakarta: Rajawali Pers, 1999).

Fazlur Rahman, "Islam and Political Action; Politics in the

Service of Religion", dalam Cities of Gods; Faith, Politics and Pluralism in Judaism, Christianity and Islam, ed. Nige Biggar dkk. (New York: Green Wood Press, 1986).

Harun Nasution, Pembaharuan Dalam Islam, Sejarah Pemikiran dan Gerakan (Jakarta: Bulan Bintang, 1986).

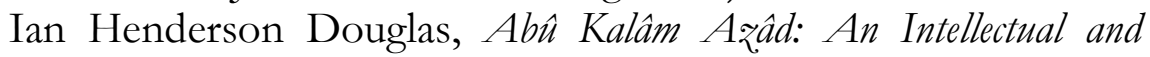
Religious Biography disunting Gail Minault dan Christian W. Troll (New Delhi: t.p., 1988).

Ibn Khaldûn, Al-Muqaddimah (Beirut: Dâr al-Fikr, t.t.).

Khalid B. Sayed, The Jamâ'ati Islâmî Movement in Pakistan, vol. 30 (t.k.: Pacific Affairs, 1958).

L. Carl Brown, Religion and State; The Muslim Approach to Politic (New York: Columbia University Press, 2000).

M. Din Syamsuddin, Islam dan Politik Era Orde Baru (Jakarta: Logos Wacana Ilmu, 2001).

"Usaha Pencarian Konsep Negara Dalam Sejarah

Pemikiran Politik Islam", Jurnal Ulumul Qur'an, vol. 4 no. 2, 1993.

Maryam Jamilah, Who is Maudoodi (Lahore: El-Matbaat-ulArabia, 1983).

Media Zaenul Bahri, "Tarekat Chistiyah; Tarekat Terkenal di India" dalam Sri Mulyati (et al.), Mengenal dan Memahami Tarekat-tarekat Muktabarah di Indonesia (Jakarta: Kencana, 2005).

Muhammad Rasyîd Ridhâ, Al-Khilâfah aw al-Imamâh al-Uz̧hmah (Kairo: Al-Manâr, t.t.).

Qâhirah, 1960). Al-Wahy al-Mubammadî (Mesir: Mathba'at al- 
Mukti Ali, Alam Pikiran Islam Modern di India dan Pakistan (Bandung: Mizan, 1995).

Munawir Syadzali, Islam dan Tata Negara; Ajaran, Sejarah, dan Pemikiran (Jakarta, UI Press, 1993).

Nurcholish Madjid, Islam Agama Peradaban; Membangun Makna dan Relevansi Doktrin Islam Dalam Sejarah (Jakarta: Paramadina, 1995).

S. Yunanto (et.al.), Gerakan Militan Islam di Indonesia dan Asia Tenggara (Jakarta: FES dan The Ridep Institute, 2004).

Samir Abdul Hamid Ibrahim, Teladan Bagi Generasi Pejuang, ter. Fathurrahman Hamid (Jakarta: Pustaka Qalami, 2004).

Suyuthi J. Pulungan, Fiqh Siyasab: Ajaran, Sejarah, dan Pemikiran (Jakarta: Raja Grafindo Persada, 1994).

Thomas Patrick Hughes, Dictionary of Islam (New Delhi: Oriental Books Print Corporation, 1976).

Tijani Abdul Qadir Hamid, Pemikiran Politik Dalam al-Qur'an, ter. Abdul Hayyie al-Kattani (Jakarta: Gema Insani Press, 2001). Ziya ul-Hasan Faruki, The Deoband School and the Demand For Pakistan (Lahore: Progressive Books, 1980). 